\title{
THE ECOLOGY OF Dipterocarpus zeylanicus PLANTATION AT INGIRIYA, SRI LANKA
}

\author{
P R Attygalle and B M P Singhakumara \\ Department of Forestry and Environmental Science, \\ University of Sri Jayewardenepura.
}

The plantation forestry in Sri Lanka began in the late $19^{\text {th }}$ century. The forest cover prevailed at that time did not warrant a rapid expansion of plantations. Later, the depletion of the forest resources compelled the Forest Department to embark on establishing plantations. A rapid increase in plantation development was noted during the $2^{\text {nd }}$ half of the $20^{\text {th }}$ century. The species sclected for plantation establishment were mostly exotics with few indigenous tree species.

Holmes as a silviculturist in the Forest Department initiated the studies on the growth performance of indigenous tree species. The present Dipterocarpus zeylanicus plantation at Ingiriya was one such location established by him in 1940. At present there are other indigenous trec species also growing in association with D. zeylanicus.

A systematic sampling design was adopted for the study. The total sample area was 1.9375 ha. The diameter at breast height and height of all the trees above $10 \mathrm{~cm}$ were recorded in $25 \mathrm{~m} \times 25 \mathrm{~m}$ plots numbering thirty-one. Seedlings and saplings in $2 \mathrm{~m} \times 2 \mathrm{~m}$ and $5 \mathrm{~m} \times 5 \mathrm{~m}$ plots were also recorded. The number of plots in each case was 124 . Important value indices for species, genera and families were calculated. Rank abundance curves were plotted. Endemic species in this plantation were recorded. Mean dbh, mean height, mean basal area, and mean top height for $D$. zeylanicus were calculated. The diameter class distribution of $D$. zeylanicus was plotted. Regression analysis was performed to observe whether any correlation exists between the dbh of $D$. zeylanicus against basal area of the same and other species.

The plantation recorded 82 species, 70 genera and 37 families. Among the 916 individual stems recorded $52 \%$ was $D$. zeylanicus. There were 248 individuals of $D$. zeylanicus per ha.

The paper highlights the floristic, status of principal species, stand parameters and suggest interventions for plantation management.

Proceedings of the Fourth Anmual Forestry and Environment Symposium 1998 of the Department of Forestry and Envirommental Science, University of Sri Jayewardenepura, Sri Lanka 